\title{
The Role of Citizenship Education in Building Bantul Community Political Participation in The Pandemic Covid 19
}

\section{T. Heru Nurgiansah}

Universitas PGRI Yogyakarta

nurgiansah@upy.ac.id

\section{Article History}

accepted 05/11/2020

approved 10/11/2020

published 01/02/2021

\begin{abstract}
This research aims to establish the political participation of Bantul people through citizenship education at the pandemic of Covid 19. The political participation of Bantul society needs to be improved so that the apathy towards politics is not increasingly faded. There are many ways to establish the political participation of Bantul people through the role of citizenship education. This method of research uses a qualitative approach. Data collection techniques use observations, interviews and literacy studies. The result of this study mentions that citizenship education has an important role and succeeded in establishing the political participation of Bantul people in the pandemic of Covid 19.
\end{abstract}

Keywords: citizenship education, political participation, Covid 19

\begin{abstract}
Abstrak
Penelitian ini bertujuan untuk membangun partisipasi politik masyarakat Bantul melalui Pendidikan Kewarganegaraan di masa pandemi Covid 19. Partisipasi politik masyarakat Bantul perlu ditingkatkan agar sikap apatis terhadap politik tidak semakin pudar. Banyak cara untuk membangun partisipasi politik masyarakat Bantul salah satunya melalui peran Pendidikan Kewarganegaraan. Metode Penelitian ini menggunakan pendekatan kualitatif. Teknik pengumpulan data menggunakan observasi, wawancara dan studi literasi. Hasil dari penelitian ini menyebutkan bahwa Pendidikan Kewarganegaraan memiliki peran penting dan berhasil membangun partisipasi politik masyarakat Bantul di masa pandemi Covid 19.
\end{abstract}

Kata kunci: pendidikan kewarganegaraan, partisipasi politik, covid 19.

Social, Humanities, and Education Studies (SHEs): Conference Series https://jurnal.uns.ac.id/shes

p-ISSN 2620-9284

e-ISSN 2620-9292 


\section{PENDAHULUAN}

Sepanjang tahun 2020 , seluruh negara disibukan dengan merebaknya virus dari Wuhan bernama corona. Keberadaan virus Covid-19 mengakibatkan sebuah pandemi (Januar Mahardhani, 2020). Indonesia telah melakukan berbagai cara untuk menanggulangi penyebaran virus tersebut dengan memberlakukan Pembatasan Sosial Berskala Besar (PSBB) yang dalam perjalannya berganti-ganti menjadi Pembatasan Sosial Berskala Mikro (PSBM), dan PSBB Transisi. Namun dalam praktiknya tidak semudah yang dibayangkan karena pandemi ini menyasar seluruh tatanan kehidupan, seperti bidang pendidikan, bidang ekonomi, bahkan bidang politik.

Dalam ranah pendidikan, pandemi ini memaksa seluruh sekolah bahkan sampai perguruan tinggi untuk menghentikan pembelajaran tatap muka dengan menerapkan kebijakan Pembelajaran Jarak Jauh (PJJ). Di bidang ekonomi lebih parah lagi, banyak pelaku usaha mikro gulung tikar dan PHK masal sehingga mengakibatkan resesi. Demikian juga dibidang politik dimana Indonesia akan melangsungkan Pilkada serentak pada 9 Desember 2020 dengan protokol kesehatan yang berbeda dengan pilkada-pilkada sebelumnya. Hal ini menjadikan tantangan tersendiri bagi pemerintah Indonesia karena menyangkut partisipasi masyarakatnya terlebih masyarakat Indonesia adalah masyarakat majemuk (Arief, 2010).

Partisipasi politik masyarakat sangat penting demi kelangsungsan sistem demokrasi Indonesia. Partisipasi politik yang tinggi di negara demokrasi pada umumnya dianggap baik (Setiawaty, 2014). Partisipasi yang baik melibatkan pergerakan masa secara sukarela tanpa intimidasi pihak manapun. Meskipun saat ini tengah terjadi pandemi namun hal itu bukan menjadi suatu alasan untuk bersikap apatis terhadap perkembangan politik di tanah air karena pada era sekarang partisipasi tidak selalu harus hadir secara langsung namun bisa menggunakan fasilitas internet. Internet dan media sosial lainnya seperti Facebook, Twitter, e-mail dan lain-lain dimanfaatkan warga muda sebagai forum diskusi dan debat politik (Rasul et al., 2015).

Partisipasi politik masyarakat juga merupakan kegiatan yang berguna untuk menjaga marwah partai politik. Partai harus dapat melahirkan dua hal yakni pemilih yang loyal dan kepercayaan terhadap partai (Damanhuri et al., 2017). Pemilih yang loyal bisa didapatkan oleh partai dengan cara menampung aspirasi mereka dan berusaha mewujudkannya. Sedangkan kepercayaan terhadap partai merupakan tanggungjawab para kader partai politik untuk selalu berperilaku secara konstitusional.

Perilaku yang sesuai dengan konstitusi ini tidak bisa didapat secara instan melainkan butuh proses panjang agar kader tersebut berperilaku sesuai dengan peraturan perundang-undangan dan sesuai dengan nilai-nilai pancasila seperti tidak melakukan korupsi, tidak melakukan berbagai macam cara untuk menjadi pemenang, dan tidak melakukan suap agar memperoleh suara terbanyak. Proses yang panjang tersebut bisa didapat melalui pendidikan, mulai dari jenjang pendidikan dasar sampai pendidikan tinggi.

Pendidikan dituntut agar lebih kreatif, inovatif, efektif, mandiri dan lebih cerdas (Nurgiansah, 2019).Pendidikan seperti ini sangat berguna ditengah pandemi covid-19. Pendidikan kreatif dan inovatif mengharuskan guru untuk menambah kompetensinya. Dan salah materi dalam pendidikan yang bisa berperan sebagai penumbuh partisipasi politik masyarakat adalah Pendidikan Kewarganegaraan. Pendidikan Kewarganegaraan merupakan bagian penting dari pembentukan warga negara yang baik (Hemafitria, 2015). Warga negara yang baik adalah warga negara yang partisipatif dalam bidang apapun termasuk politik. Pendidikan kewarganegaraan mempunyai tujuan yaitu mewujudkan warga negara sadar bela negara berlandaskan pemahaman politik kebangsaan (Fitasari et al., 2015). 


\section{METODE}

Penelitian ini menggunakan metode kualitatif. Metode penelitian kualitatif sering disebut dengan metode penelitian naturalistik (Nurgiansah \& Widyastuti, 2020). Hal ini karena metode kualitatif merupakan penelitian secara mendalam dan menyeluruh sehingga data yang diperoleh sesuai dengan fakta yang terjadi di lapangan. Objek penelitian di lakukan di kabupaten Bantul dan subjek penelitian dilakukan terhadap masyarakat di kecamatan se-kabupaten Bantul. Teknik pengumpulan data melalui observasi, wawancara, dokumentasi, dan literasi.

\section{HASIL DAN PEMBAHASAN}

Partisipasi politik masyarakat merupakan hal yang paling elementer dalam kegiatan politik praktis terlebih bagi negara Indonesia yang menganut sistem demokrasi. Partisipasi yang banyak mengindikasikan bahwa kegiatan politik berjalan sebagaimana mestinya dimulai dari proses rekrutment tokoh atau figur partai, pemilihan bakal calon, sampai selesai pemilihan.

Masyarakat Bantul sangat partisipatif terhadap kegiatan politik meskipun tengah berjalan di masa pandemi Covid-19. Alasan mereka untuk tetap berpartisipasi karena rasa kepedulian terhadap kehidupan bermasyarakat. Masyarakat Bantul sadar akan pentingnya rotasi kepemimpinan agar menghasilkan kebijakan-kebijakan yang pro rakyat. Selain itu masyarakat Bantul beranggapan bahwa partisipasi politik bisa semakin meningkat jika masyarakat melek politik melalui kegiatan pengajaran dan pelatihan seperti melalui Pendidikan Kewarganegaraan. Pendidikan kewarganegaraan sebagai kajian politik tidak berorientasi untuk mendukung rezim atau kekuatan politik tertentu (Aulia \& Arpannudin, 2019). Artinya Pendidkan Kewarganegaraan hanya sebuah media penyampaian pengetahuan politik terhadap masyarakat. Pendidikan Kewarganegaraan bersikap netral tanpa condong berpihak kepada salah satu kader politik yang mengikuti kontestasi pemilihan umum.

Partisipasi masyarakat akan semakin membaik jika ditunjang dengan berbagai fasilitas memadai seperti akses jalan menuju lokasi pemilihan. Juga dengan sarana media sosial sebagai media yang berfungsi untuk mengenalkan para kandidat yang akan bersaing. Masyarakat juga perlu mengetahui apa saja yang menjadi visi-misi dari para calon kepala daerah agar mereka tidak salah memilih pemimpin. Kesalahan dalam memilih akan memberikan penyesalan dikalangan masyarakat dan dapat menumbuhkan kembali sikap apatisme sehingga mereka enggan berpartisipasi.

\section{SIMPULAN}

Pendidikan Kewarganegaraan berperan sangat efektif terhadap perilaku partisipasi masyarakat Bantul di tengah-tengah wabah pandemi covid-19. Partisipasi masyarakat dapat terlihat dari beberapa indikator, pertama masyarakat tahu jadwal pelaksanaan pemilihan kepala daerah setempat yakni pada 9 Desember 2020. Yang kedua, masyarakat tahu dan mengenal calon kepala daerah yang menjadi kontestan, yang ketiga, masyarakat tahu visi dan misi para calon dan mengikuti pelaksanaan debat yang disiarkan secara langsung oleh televisi nasional. Dan yang terakhir masyarakat mau dan bersedia menyalurkan suara mereka saat pencoblosan dengan mematuhi protokol kesehatan seperti memakai masker, mencuci tangan, dan menjaga jarak.

\section{DAFTAR PUSTAKA}

Arief, U. (2010). Mencipakan Sistem Politik Berdasarkan Pancasila Sebagai Upaya Peningkatan Ketahanan Nasional. Jurnal Sosial Humaniora, 3(2), 139-147. https://doi.org/10.12962/j24433527.v3i2.645 
Aulia, S. S., \& Arpannudin, I. (2019). Pendidikan Kewarganegaraan Dalam Lingkup Sosio-Kultural Pendidikan Non-Formal. Jurnal Civic Education: Media Kajian Pancasila Dan Kewarganegaraan, 3(1), 1. https://doi.org/10.36412/ce.v3i1.902

Damanhuri, Rahman, I. N., \& Juwandi, R. (2017). Kajian Tentang Peran Partai Politik Dalam Upaya Peningkatan Partisipasi Politik Warga Negara Dalam Pilkada Banten. UCEJ: Untirta Civic Education Journal, 2(1), 168-181.

Fitasari, D. N., Tohari, M., \& Praptiningsih. (2015). Pengaruh Penggunaan Media Video pembelajaran Terhadap Minat Belajar Mata Pelajaran Pendidikan Kewarganegaraan Siswa Kelas IX MTs NU Ungaran. Jurnal Wasdapa UNDARIS, 3(1), 55-67.

Hemafitria. (2015). Pembelajaran PKn Sebagai Pendidikan Politik Pemilih Pemula. Jurnal Edukasi, 13(2), 175-189.

Januar Mahardhani, A. (2020). Menjadi Warga Negara yang Baik pada Masa Pandemi Covid-19: Persprektif Kenormalan Baru. Jurnal Pancasila Dan Kewarganegaraan, 5(2), 65-76. https://doi.org/10.24269/jpk.v5.n2.2020.pp65-76

Nurgiansah, T. H. (2019). Pemutakhiran Kurikulum Pendidikan Kewarganegaraan di Era Revolusi Industri 4.0. Prosiding Seminar Kewarganegaraan Universitas Negeri Medan, 1(1), 95-102.

Nurgiansah, T. H., \& Widyastuti, T. M. (2020). Membangun Kesadaran Hukum Mahasiswa PPKn UPY Dalam Berlalu Lintas. Civic Edu: Jurnal Pendidikan Kewarganegaraan Universitas Pasundan, 2(2), 97-102. https://doi.org/10.1017/CBO9781107415324.004

Rasul, N., A. Rahim, S., \& Salman, A. (2015). Penggunaan Media, Norma Kewarganegaraan Dan Partisipasi Politik Dalam Era Transisi Ke Demokrasi Di Indonesia. Jurnal Komunikasi, Malaysian Journal of Communication, 31(1), 187204. https://doi.org/10.17576/jkmjc-2015-3101-10

Setiawaty, D. (2014). Mendorong Partisipasi Pemilih Muda Melalui Pendidikan Politik Yang Programatik. Jurnal Islamic Review, 3(1), 117-146. 